\title{
都市下水処理によるアニオン界面活性剤 \\ 除去に関する検討
}

\author{
関口一・三浦千明・八木良一・大場 健 吉 \\ ライオン油脂株式会社（東京都江戸川区平井 7-13-12）
}

\section{Individual Removals of Anionic Surfactants in Municipal Sewage Treatment Plants}

Hitoshi Sekiguchi, Kazuaki Miura, Ryōichi Yagi and Kenkichi ŌBa Lion Fat \& Oil Co. Ltd,(7-13-12, Hirai, Edogawa-ku, Tokyo)

The individual removals of linear alkylbenzene sulfonate (LAS), branched alkylbenzene sulfonate (ABS), alpha olefin sulfonate (AOS) and sulfate type surfactants in sewage treatment plants have been examined for one year. This was accomplished by infra-red spectroscopic analysis of anionic surfactants in raw municipal sewage and effluent from sewage treatment plants.

The individual removals of anionic surfactants in sewage treatment plant were ca. 85\%, $35 \%$, and $100 \%$ for LAS, ABS, and AOS and sulfate-type surfactants, respectively. Then, the removals of biochemical oxygen demand (BOD) and soluble total organic carbon (TOC) were 90 and $68 \%$ respectively.

\section{1 緒言}

合成アニオン界面活性剂の下水処理場における除去性 についてはこれまでに $\mathrm{Mann}^{1), 2), 3)}$ や Janicked) など によって実験用にコントロールされた条件下で各界面活 性剂別にフィードしながらコミュニティプラントを用い た野外実験やモデル実験によって，メチレンブルー活性 物質 (MBAS) あるいは有機物としての除去率から検討 されている。しかし実際には合成洗剤は都市下水中で相 互に, あるいは他の有機物と共存し, 特に実験用にコン トロールされるようなことなく処理される。そこでこの ような通常の運転状態にある都市下水処理場において各 種の界面活性剤が実際にどの程度除去されているかは非 常に興味墚い問題である。これまでにこの種の検討が充 分なされなかったのはおのおのの界面活性剂を同時に分 離して分析することができなかった点にある。最近，関 ロら によっって開発された分析法によってこの点が解決 されたので, 通常の運転状態にある下水処理場における 直鎖アルキルベンゼンスルホン酸塩(LAS), 枝分れ鎖ア ルキルベンゼスルホン酸塩 (ABS)， ホン酸塩 (AOS) および硫酸エステル塩 (Sulfates) の 各個別の除去性 (吸着, 分解を含む) について検討を行 った。また同時に溶解性全有機炭素 (TOC) および全リ ン (Total-P) 中に占める洗凰由来の有機炭素とリンの 割合を推定した。

\section{2 実験}

都市下水処理場の二次処理（活性污泥法）による合成 アニオン界面活性剤の個々の除去性を検討するため, 1 年間にわたって 2 加所の処理場の流入生下水と放流水中 のMBAS 濃度とアニオン界面活性剤の組成を分析した。 両下水処理場とも生下水と放流水の $24 \mathrm{hr}$ にわたる 1 日 の平均的組成を代表する合成試料を採取して分析に供し た。両下水処理場の処理能力は処理場 $\mathrm{A}$ が $450,000 \mathrm{~m}^{3}$ / day, B が $360,000 \mathrm{~m}^{3} /$ day て両処理場とも, 合流式処 理場である。分析は MBAS 濃度6), アニオン界面活性 剂組成 ${ }^{5)}$, 全有機炭素濃度 (TOC; Beckman 社製 TOC 分析計 915 型使用) 全酸素要求量 (TOD; Ionics 社製 TOD 分析計 225 型使用), BOD および Total- ${ }^{7)}$ に ついて行った。

アニオン界面活性剂組成の分析法の原理は次に示すと おりである。まずアニオン界面活性剤をメチレンブルー との複合体としてクロロホルムで抽出する。次に加水分 解によってサルフェート系界面活性剤をスルホネート系 のものと分離, 除去する。スルホネート系界面活性剤は AOS が存在した場合を想定してその二重結合を飽和す るため水素添加を行った後, イオン交換によってメチレ ンブルーをはずす。この操作によってメチレンブルーは イオン交換樹脂に吸着され, 界面活性剤は流出液中に $\mathrm{R}-\mathrm{SO}_{3} \cdot \mathrm{H}$ とし得られる。さらに塩化チオニルによって 
スルホニルクロリド誘導体とした後，IR 分析によって LAS, ABS および AOS の組成を求める。IR 分析時 のキーバンドは LAS が $640 \mathrm{~cm}^{-1}, \mathrm{ABS}$ が $618 \mathrm{~cm}^{-1}$, AOS が $524 \mathrm{~cm}^{-18)}$ である。またサルフェート系界面 活性剂の含有量は加水分解による MBAS の減少量から 求める。

また洗剤に由来する有機炭素およびリンの 濃度は次式によって推定した。

$$
\begin{aligned}
& \text { Det. }- \text { TOC }=\text { MBAS } \times \frac{349.6}{444.6} \times 0.60 \\
& \text { Det. }-\mathrm{P}=\text { MBAS } \times \frac{349.6}{444.6} \times 0.17
\end{aligned}
$$

$349.6: 1971$ 年の原料消費量から求めた ニオン系界面活性戍の平均分子量。

444.6 : MBAS 分析用標準物質ジー2-エチル ヘキシルスルホコハク酸ナトリウム の分子量。

0.60 : 有機炭素濃度/界面活性剤濃度の計 算値, 各界面活性剂別の值を使用量 で加重平均して求めた。

$0.17: 1971$ 年の洗剂用として 使用された リンの量を同年の洗剂用として使用 されたアニオン界面活性剤量で除し た值。

\section{3 結果および考察}

MBAS 濃度と除去率は Table-1 に示す ように，濃度は生下水中で $5.7 \sim 14.0 \mathrm{mg} / l$,
平均 $8.3 \mathrm{mg} / l$, 放流水中で $0.3 \sim 4.7 \mathrm{mg} / l$, 平均 1.9 $\mathrm{mg} / l$, 除去率は 42.0 94.7\% 平均 $77 \%$ であった。 12 月に低除去率が観察されたのは降雨による影響と思われ る。

生下水执よび放流水中のアニオン界面活性剂の組成と 各個別の除去率ならびに BOD，TOC，TOD の分析結

Table-1 Concentration and removal of MBAS*

\begin{tabular}{r|c|c|c|c|c|c}
\hline \multirow{2}{*}{$\begin{array}{c}\text { Sewage } \\
\text { treatment } \\
\text { plant }\end{array}$} & \multicolumn{3}{|c|}{$\mathrm{A}$} & \multicolumn{3}{|c}{$\mathrm{B}$} \\
\cline { 2 - 7 } & $\begin{array}{c}\text { Influent } \\
(\mathrm{mg} / l)\end{array}$ & $\begin{array}{c}\text { Effluent } \\
(\mathrm{mg} / l)\end{array}$ & $\begin{array}{c}\text { Removal } \\
(\%)\end{array}$ & $\begin{array}{c}\text { Influent } \\
(\mathrm{mg} / l)\end{array}$ & $\begin{array}{c}\text { Effluent } \\
(\mathrm{mg} / l)\end{array}$ & $\begin{array}{c}\text { Removal } \\
(\%)\end{array}$ \\
\hline 1972 Oct. & 8.4 & 1.8 & 78.6 & 8.1 & 2.3 & 71.6 \\
Nov. & 7.9 & 1.7 & 78.5 & 7.3 & 1.8 & 75.3 \\
Dec. & 7.2 & 3.1 & 56.9 & 8.1 & 4.7 & 42.0 \\
1973 Jan. & 8.4 & 1.8 & 78.5 & - & - & - \\
Feb. & 7.7 & 1.3 & 83.1 & 7.5 & 1.7 & 77.3 \\
Mar. & 9.1 & 2.1 & 76.9 & 9.1 & 1.8 & 80.2 \\
Apr. & 10.4 & 3.3 & 68.3 & - & - & - \\
May & 10.6 & 1.2 & 88.7 & 14.0 & 1.3 & 90.7 \\
Jun. & 9.1 & 2.4 & 71.4 & - & - & - \\
Jul. & 8.8 & 2.6 & 70.5 & - & - & - \\
Aug. & 5.7 & 0.3 & 94.7 & 6.5 & 1.2 & 81.5 \\
Sep. & 5.1 & 0.3 & 94.1 & 6.5 & 0.8 & 87.7 \\
\hline Min. & 5.1 & 0.3 & 56.9 & 6.5 & 0.8 & 42.0 \\
Max. & 10.6 & 3.3 & 94.7 & 14.0 & 4.7 & 90.7 \\
Mean & 8.2 & 1.8 & 78.4 & 8.4 & 2.0 & 75.8 \\
\hline
\end{tabular}

* Determined as sodium di-2-ethylhexyl sulfosuccinate.

Table-2 Composition of anionic surfactants in sewage and individual removal in sewage treatment, and data of BOD, TOC and TOD.

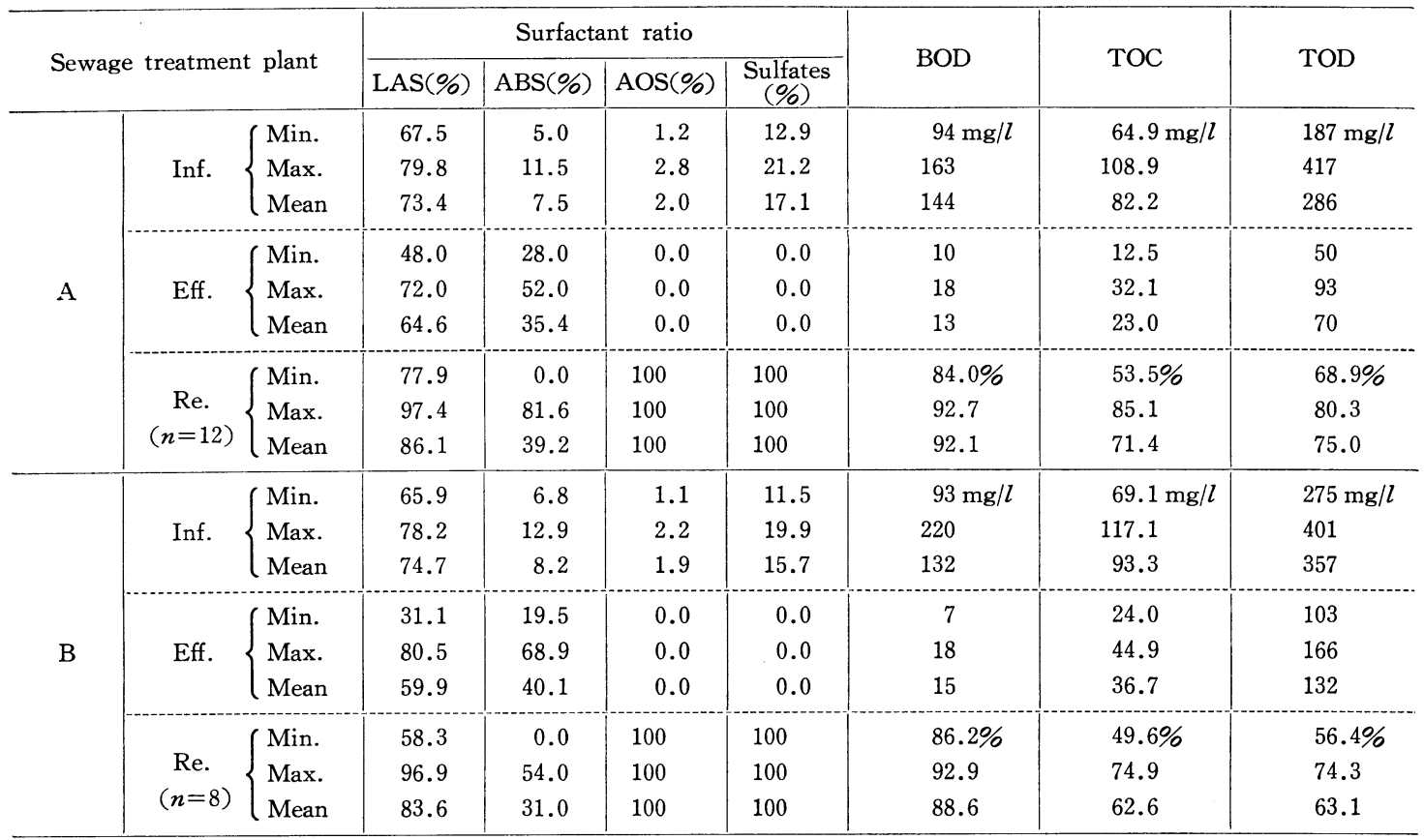

Inf. $\cdots$ Influent, Eff. $\cdots$ Effluent, Re. $\cdots$ Removal 
Table-3 Load of phosphorus and TOC originating from detergents in raw municipal sewage

\begin{tabular}{|c|c|c|c|c|c|c|}
\hline \multirow{2}{*}{$\begin{array}{l}\text { Sewage } \\
\text { treatment } \\
\text { plant }\end{array}$} & \multicolumn{3}{|c|}{ Phosphorus } & \multicolumn{3}{|c|}{ TOC } \\
\hline & $\begin{array}{c}\text { Det. }-\mathrm{P} \\
(\mathrm{mg} / l)\end{array}$ & $\underset{(\mathrm{mg} / l)}{\text { Total-P }}$ & Det. - $\mathrm{P} \%$ & $\left|\begin{array}{c}\text { Det. - TOC } \\
(\mathrm{mg} / l)\end{array}\right|$ & $\begin{array}{c}\mathrm{TOC} \\
(\mathrm{mg} / l)\end{array}$ & $\begin{array}{l}\text { Det. } \\
\text {-TOC } \%\end{array}$ \\
\hline Min. & 0.7 & 3.4 & 11.6 & 2.4 & 64.9 & 3.2 \\
\hline A $\{$ Max. & 1.4 & 5.7 & 31.1 & 5.0 & 108.9 & 5.8 \\
\hline Mean & 1.1 & 4.3 & 25.3 & 3.9 & 82.2 & $4.7(n=12)$ \\
\hline \multirow{3}{*}{$\mathrm{B}\left\{\begin{array}{l}\text { Max. } \\
\text { Mean }\end{array}\right.$} & 0.9 & 2.9 & 17.0 & 3.1 & 69.1 & 3.1 \\
\hline & 1.8 & 5.0 & 42.3 & 6.6 & 117.1 & 6.7 \\
\hline & 1.1 & 4.1 & 27.4 & 4.0 & 93.3 & $4.3(n=8)$ \\
\hline
\end{tabular}

付随的な研究として都市下水中の污 濁物質中に占める洗剂由来物質の割合 についてリンと有機物について検討し た。Table-3 に都市下水中での洗剤 の使用によって生ずるリンと TOC 負 荷の 割合を示す。この割合の算出は 2 実験に示すように MBAS 濃度の実 測値と統計的数值を基に行った。

都市下水中における洗剤に由来する リンおよび TOC のそれぞれ Total$\mathrm{P}, \mathrm{TOC}$ 中に占める割合は平均值で

果を Table-2 に示す。生下水中の LAS, ABS, AOS および Sulfates の比率は両処理場の平均でおのおの約 74\%,8\%,2\%,16\% であった。この值はアニオン界面 活性剤の原料消費量から推定される值とおおむ社一致し ているものと考えられる。また放流水中には平均值で LAS が 63\%, ABS が 37\% の割合で存在し, AOS と Sulfates は検出されなかった。下水処理による各界面活 性剂の個別の除去率は平均で LAS が 85\%, ABS が $35 \%$, AOS と Sulfates が 100\% であった。ここで, BOD 除去率が約 90\%, TOC 除去率が約 68\% であるこ とと比較して $85 \%$ という LAS の除去率はほぼ理解で きる值であろう。しかし, さらに被処理特性がすぐれた 界面活性剤を指向するなら, その候補としては本研究に おいても示されたように, LAS に比較していっそう分 解除去されやすい特性から, AOS や硫酸エステル塩系 界面活性剤などがあげられる。また，TOD は TOC と ほぼ同様な除去率を示した。
$26 \%$ および $4.5 \%$ であった。

本研究を実施するに当たり, 試料の採取等, 終始御指導を頂 きました両下水処理場関係者各位, ならびにデータ発表に際し， 裁可および 助言を賜わりました 東京都下水道施設管理担当の方 に心から感謝の意を表します。

(昭和 49 年 11 月 1 日受理)

\section{文献}

1) A.H. Mann, V.W. Reid, J. Amer. Oil Chem. Soc., 48, 588-594 (1971)

2) A.H. Mann, V.W. Reid, J. Amer. Oil Chem. Soc., 48, 794-797 (1971)

3) A.H. Mann, V.W. Reid, J. Amer. Oil Chem. Soc., 48, 798-799 (1971)

4) W. Janicke, Water Research, 5, 917-931 (1971)

5) H. Sekiguchi et al., (投稿中)

6) D.C. Abbott, Analyst, 87, 286-293 (1962)

7) A.P.H.A., Standard Methods for Examination of Water and Waste Water, p. 526-530 (1971) New York

8）永井敏雄ら, 工化, 73, 1968-1970 (1970) 